\title{
A Cultura da Cópia: Estudo sobre o Compartilhamento de Arquivos e a Prática da Pirataria Virtual
}

\author{
Daniel Jorge Teixeira Cesar \\ Orientador: Prof. Dr. Michelangelo Giotto Santoro Trigueiro \\ Curso: Mestrado em Sociologia \\ Data da Defesa: 12.04.2013
}

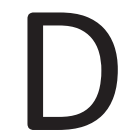
esde o começo dos anos 2000, com os avanços da tecnologia que permitiu a cópia de mídias físicas e a transmissão de arquivos digitais em rede, o compartilhamento de arquivos pela internet, ou pirataria virtual, como é vulgarmente chamada, por caracterizar downloads não autorizados de bens culturais e intelectuais protegidos por direitos autorais, vem se tornando uma prática cada vez mais comum. Estima-se que cerca de $30 \%$ do tráfego de informação pela internet ocorra por essa modalidade de troca de arquivos entre usuários, que permite acesso a bens culturais e intelectuais sem pagar pelos mesmos, resultando no que indústrias e governo percebem como um problema cada vez maior, especialmente para as indústrias fonográfica e cinematográfica, que perdem o controle sobre a reprodução e distribuição de seus produtos. 0 acesso a tecnologias que possibilitam copiar dados e retransmiti-los para outros computadores em alta velocidade força a transformação do modelo econômico pela reorganização do consumo e abre o debate acerca da propriedade intelectual e imaterial sobre a exploração dos direitos autorais pela indústria. A pirataria virtual é um indício do surgimento de um novo movimento político e social pela liberdade de informação, que se aproxima das disputas pelos meios de produção em sociedades industriais. Com este trabalho pretendo, mediante o contato "ciberetnográfico" com usuários do compartilhamento de arquivos, mostrar como percebem a prática da pirataria virtual e sua tendência às transformações sociais através da formação de um partido político.

Palavras-chave: Compartilhamento, Pirataria, Propriedade Intelectual, Direito Autoral, Política. 